\title{
PROGNOSTIC IMPACT OF LOW ESTROGEN AND PROGESTERONE POSITIVITY IN LUMINAL B (HER2 NEGATIVE) BREAST CANCER
}

\author{
Jasmina Rajc ${ }^{1,2}$, Irena Fröhlich ${ }^{1,2}$, Milanka Mrčela ${ }^{1,2}$, Ilijan Tomaš ${ }^{2,3}$ and Josipa Flam ${ }^{2,3}$ \\ ${ }^{1}$ Department of Pathology and Forensic Medicine, Osijek University Hospital Centre, Osijek, Croatia; \\ ${ }^{2}$ Faculty of Medicine, Josip Juraj Strossmayer University of Osijek, Osijek, Croatia; \\ ${ }^{3}$ Department of Oncology, Osijek University Hospital Centre, Osijek, Croatia
}

\begin{abstract}
SUMMARY - Luminal B (HER2 negative) subtype is the most diversiform type of breast cancers, with a high Ki-67 proliferation index (>20\%) or/and low progesterone ( $\mathrm{PR} ;<20 \%)$ with various intensity and distribution of hormone receptors. Considerable difference has also been noticed in disease outcome, wherefore there is the need for a more detailed classification of this tumor subtype. The clinical and pathologic parameters of 147 luminal B (HER2 negative) breast cancers were examined. The expression of hormone receptors in correlation with other prognostic factors and disease outcome was analyzed by Kaplan-Meier curves and multivariate Cox regression analysis. The KaplanMayer analysis showed that low positivity of estrogen (ER) and PR receptors in tumors was associated with a significantly worse disease outcome (overall survival (ER), $\mathrm{p}=0.020$; disease free survival (ER), $\mathrm{p}=0.019$; overall survival (PR), $\mathrm{p}=0.026$; disease free survival $(\mathrm{PR}), \mathrm{p}=0.038)$ ), unlike Ki-67, which did not show a statistically significant connection (overall survival, $\mathrm{p}=0.343$; disease free survival, $\mathrm{p}=0.322$ ). The intensity of receptor staining and $\mathrm{Ki}-67$ relative to other histopathologic prognostic factors showed a statistically significant correlation solely with histologic grade of tumor. By using the Cox regression model, PR proved to be an independent prognostic factor for overall survival $(p=0.004)$ and disease free survival $(p=0.029)$. The luminal B (HER2 negative) breast cancer with low expression of hormone receptors, independent of the Ki-67 proliferation index, and in correlation with a higher histologic grade, could be a unique subtype of cancer.
\end{abstract}

Key words: Breast neoplasms; Receptors, estrogen; Receptors, progesterone; Disease-free survival; Croatia

\section{Introduction}

Breast cancer is still the most common malignant tumor in women and a significant healthcare issue ${ }^{1}$. As it is well known, breast cancer is a heterogeneous disease $^{2}$, the course and outcome of which is assessed by prognostic parameters including tumor size, histologic grade, histologic subtype and lymph node involvement, along with estrogen (ER) and progesterone $(\mathrm{PR})$ receptor expression ${ }^{3}$. Different breast cancer clas-

Correspondence to: Jasmina Rajc, MD, Department of Pathology and Forensic Medicine, Osijek University Hospital Centre, Josipa Huttlera 4, HR-31000 Osijek, Croatia

E-mail: rajcjasmina@gmail.com

Received May 25, 2017, accepted August 21, 2017 sifications use these parameters to most accurately assess disease outcome and modify oncologic therapy by the more individualistic approach. However, the most recent molecular research has attributed a new classification that divides breast cancer into 4 subtypes (luminal A, luminal B, HER2 positive and basal-like). This classification was accepted at the $12^{\text {th }}$ St. Gallen International Breast Cancer Conference held in 2011, and it is now widely used. The classification itself is based primarily on the expression of single gene groups (expression of ER and PR in luminal subtypes or HER2 and proliferation gene groups in basal-like and HER2 positive subtypes), although the financially more acceptable and accessible immunohistochemical interpretation of ER, PR and HER2 receptors, as well as 
Ki-67 proliferation index, which are needed to place the tumor in a precise group, has been accepted as an appropriate replacement method. By using the immunohistochemistry method, breast cancers are also classified into four groups: luminal A, luminal B, HER2 positive and triple negative ${ }^{4}$.

The hormone positive tumors fall into the category of luminal A or luminal B subtypes, mostly dependent on the $\mathrm{Ki}-67$ proliferation index, which is higher in the luminal B subtype. At the $13^{\text {th }}$ St. Gallen Consensus Conference held in 2013, a cut-off value of $20 \%$ was proposed for Ki-67; using it, tumors with higher values are placed into luminal $\mathrm{B}$ subtype, as well as those tumors that have weaker expression (less than 20\%) of $\mathrm{ER}$ or $\mathrm{PR}$, in addition to tumors that have one negative receptor ${ }^{5}$. Luminal A subtype cancer have better and more favorable outcome and it is also well known that they have better response to hormonal therapy than luminal B cancers; in fact, it is the most heterogeneous subtype of breast cancer. The Ki-67 proliferation index has a considerable range in this subtype of cancer (20\%-100\%), but even more diversiform is the positivity span of hormones that can differ from only focal mild positivity in a single tumor cell to diffuse intensive positivity in all tumor cells ${ }^{6}$. Given that the heterogeneity of this tumor subtype is also reflected in disease outcome ${ }^{7}$, the question arises whether the luminal B (HER2 negative) population with lower Ki67 proliferation index and more intensive and diffuse positivity of receptors is the one that is more similar to the luminal A subtype (with better prognosis), both by response to hormone therapy and less aggressive behavior, and whether this group of luminal B (HER2 negative) cancers can be divided into subgroups of those with better and worse outcomes (by immunohistochemical assessment of ER, PR and $\mathrm{Ki}-67$ and in correlation with the common prognostic parameters).

Unlike other prognostic parameters (lymph node status, tumor grade, lymphovascular invasion), the role of which in the assessment of tumor behavior and thus the appropriate therapeutic guideline is relatively distinct, the level of tumor positivity needed for inclusion of endocrine therapy in ER positive tumors is still partly unclear. Should tumors with high positivity stains, with proved better outcome receive adjuvant chemotherapy, is also a question that should be answered $^{8}$.

This study included 147 luminal B (HER2 negative) breast cancers that were determined by immuno- histochemical analysis of ER, PR, HER2 and $\mathrm{Ki}-67$ proliferation index, in order to establish the connection of usual prognostic parameters with hormone receptor staining intensity and percentage of positive cells, along with $\mathrm{Ki}-67$ proliferation index, in correlation with clinical outcome (overall survival (OS) and disease free survival (DFS)).

\section{Material and Methods}

A retrospective study included 147 invasive breast cancers from patients having undergone surgical tumor resection in 2006, 2007 and 2008 at the Department of Surgery, Osijek University Hospital Centre in Osijek. Archival materials from the Department of Pathology and Forensic Medicine, Osijek University Hospital Centre, were used to record and re-evaluate the histopathologic data. Using a four-marker immunopanel (ER, PR, HER2 and Ki-67), luminal B (HER2 negative) specimens were isolated, according to the 2011 St. Gallen International Expert Consensus criteria, as revised at the 2013 and 2015 Conferences (Ki-67 $\geq 20 \%$ and/or PR $<20 \%$ ).

The immunohistochemical analysis was performed on formalin fixed, paraffin embedded tissue on a Ventana automated slide stainer. The following rabbit monoclonal primary antibodies were used: Confirm anti-estrogen receptor (ER) (clone SP1), Confirm anti-progesterone receptor (PR) (clone 1E2), Confirm anti-Ki-67 (clone 30-9) and Pathwayanti HER-2/neu (clone 4B5). These antibodies were optimally diluted for use with the Ventana ultra VIEW Universal DAB detection kit. The slides were evaluated under a light microscope by two independent pathologists.

To determine the ER and PR receptor status, scoring by the method proposed by Allred et al. was used ${ }^{9}$. Percentage of positive cells $(0=$ no positive cells; $1=<1 \% ; 2=1 \%-10 \% ; 3=11 \%-33 \% ; 4=34 \%-66 \%$; and $5=>67 \%$ of positive cells $)$ and intensity $(0=$ none; $1=$ weak; 2 = intermediate; and 3 = strong intensity) were added, yielding a score of 0-8. HER-2 immunostaining was graded as follows: $0,1+, 2+$, and $3+$. Intensity scores of 0 or $1+$ were designated as negative expression and $3+$ as positive expression for HER2/neu. The $2+$ score was further subjected to silver-enhanced in situ hybridization (SISH) analysis.

The Ki-67 proliferation index was measured according to the recommendations from the International Ki-67 in the Breast Cancer Working Group ${ }^{10}$. 
Histologic classification of tumor specimens was based on the World Health Organization criteria ${ }^{11}$, and tumors were graded according to the ScarffBloom Richardson classification as modified by Elston and Ellis ${ }^{12}$. Tumor size was divided into four groups $(>0.5 \leq 1.0 \mathrm{~cm} ;>1 \leq 2 \mathrm{~cm} ;>2 \leq 5 \mathrm{~cm}$; and $>5 \mathrm{~cm})$ and lymph node status into four groups, as follows: N0 (negative lymph node); N1 (1-3 positive nodes); N2 (4-9 positive nodes); and N3 ( $>10$ positive nodes).

Demographic and clinical features of the patients were obtained from hospital charts. Patients having a metastatic disease at presentation were excluded. DFS was determined as the period without locoregional or distant recurrence. Locoregional recurrence was defined as a tumor occurring at the resection site and distant recurrence was defined as a tumor outside the site of resection including the liver, adrenals, lungs or bones. The recurrence was diagnosed by radiologic image or biopsy.

\section{Statistical analysis}

The data collected were statistically analyzed using the MedCalc Statistical Software version 16.4.2 (MedCalc Software bvba, Ostend, Belgium; https:// www.medcalc.org; 2016). The survival time was calculated in months starting from the date of the surgery. Fisher exact test for categorical data was used to analyze any relationship between the clinical and histopathologic factors. Survival analysis of censored data was performed using the Kaplan-Meier method. The log-rank test was used to compare survival data curves. The univariate and multivariate stepwise proportional-hazard analysis (Cox model) was performed to identify the variables significantly associated with survival. Cut-off values were defined using the ROC analysis.

Categorical data were expressed as absolute and relative frequencies, whereas numerical data and scores were expressed with median and interquartile range. The level of statistical significance was set at $\mathrm{p}<0.05$.

\section{Results}

In the study sample, the median age was 62 (53$70)$, range 33 to 83 years. Most of the tumors, 102 $(69.38 \%)$ were diagnosed as not otherwise specified (NOS), whereas $22(14.96 \%)$ were invasive lobular
Table 1. Patient and tumor characteristics

\begin{tabular}{|c|c|}
\hline & n (\%) \\
\hline \multicolumn{2}{|l|}{ Histology } \\
\hline not otherwise specified & $102(69.4)$ \\
\hline lobular & $22(15.0)$ \\
\hline other & $23(15.6)$ \\
\hline \multicolumn{2}{|l|}{ Tumor size $(\mathrm{cm})$} \\
\hline$>0.5 \leq 1.0$ & $17(11.6)$ \\
\hline$>1 \leq 2$ & $50(34.0)$ \\
\hline$>2 \leq 5$ & $68(46.3)$ \\
\hline$>5$ & $12(8.2)$ \\
\hline \multicolumn{2}{|l|}{ Grade } \\
\hline 1 & $64(43.5)$ \\
\hline 2 & $64(43.5)$ \\
\hline 3 & $19(12.9)$ \\
\hline \multicolumn{2}{|l|}{ Lymph node status } \\
\hline No & $66(44.9)$ \\
\hline N1 (1-3) & $34(23.1)$ \\
\hline $\mathrm{N} 2(4-9)$ & $30(20.4)$ \\
\hline $\mathrm{N} 3(>10)$ & $17(11.6)$ \\
\hline Total & $147(100.0)$ \\
\hline
\end{tabular}

cancers and 23 (15.66\%) were pooled as 'other types' in this study. As many as 128 (87.00\%) cases were well or moderately differentiated (grade 1 and 2), and only 19 (13.00\%) were poorly differentiated (grade 3 ). Lymph node metastases were recorded in $55.10 \%$ of study patients (Table 1). Significantly, most of the tumors were $>2 \leq 5 \mathrm{~cm}$ in size (Table 1 ).

The median follow up period was 80.7 months with the interquartile range of 35.7-103.5 months and total range of 1.9-128.2 months. During the study period, 53 (36.1\%) patients died. Recurrences were reported in $45(30.7 \%)$ patients, as follows: local recurrences in $7(4.8 \%)$ and distant recurrences in 38 (25.9\%) cases.

In this group of patients, there were no ER negative tumors, 9 tumors were PR negative, and another 8 tumors had less than $20 \%$ of PR positive staining cells. All of these tumors had $\mathrm{Ki}-67$ proliferation index above $20 \%$.

The ER and PR scores, as well as Ki-67 proliferation index were significantly correlated with tumor grade (ER p=0.037; PR p=0.008; and Ki-67 p<0.001). However, ER and PR scores along with $\mathrm{Ki}-67$ proliferation index were not associated with other parame- 
Table 2. Estrogen correlation with other parameters

\begin{tabular}{|c|c|c|c|c|c|}
\hline ER score & $3-5$ & 6 & 7 & 8 & $\mathrm{p}^{*}$ \\
\hline \multicolumn{6}{|l|}{ Histology } \\
\hline NOS & $21(67.7)$ & $27(90.0)$ & $28(65.1)$ & $26(60.5)$ & \multirow{3}{*}{0.184} \\
\hline lobular & $5(16.1)$ & $2(6.7)$ & $7(16.3)$ & $8(18.6)$ & \\
\hline others & $5(16.1)$ & $1(3.3)$ & $8(18.6)$ & $9(20.9)$ & \\
\hline \multicolumn{6}{|c|}{ Tumor size $(\mathrm{cm})$} \\
\hline$>0.5 \leq 1.0$ & $4(12.9)$ & $2(6.7)$ & $3(7.0)$ & $8(18.6)$ & \multirow{4}{*}{0.291} \\
\hline$>1 \leq 2$ & $12(38.7)$ & $6(20.0)$ & $17(39.5)$ & $15(34.9)$ & \\
\hline$>2 \leq 5$ & $13(41.9)$ & $18(60.0)$ & $18(41.9)$ & $19(44.2)$ & \\
\hline$>5$ & $2(6.5)$ & $4(13.3)$ & $5(11.6)$ & $1(2.3)$ & \\
\hline \multicolumn{6}{|l|}{ Grade } \\
\hline 1 & $12(38.7)$ & $11(36.7)$ & $18(41.9)$ & $23(53.5)$ & \multirow{3}{*}{0.037} \\
\hline 2 & $13(41.9)$ & $11(36.7)$ & $24(55.8)$ & $16(37.2)$ & \\
\hline 3 & $6(19.4)$ & $8(26.7)$ & $1(2.3)$ & $4(9.3)$ & \\
\hline \multicolumn{6}{|c|}{ Lymph node status } \\
\hline No & $14(45.2)$ & $9(30.0)$ & $18(41.9)$ & $25(58.1)$ & \multirow{4}{*}{0.116} \\
\hline N1 (1-3) & $8(25.8)$ & $7(23.3)$ & $13(30.2)$ & $6(14.0)$ & \\
\hline N2 (4-9) & $8(25.8)$ & $8(26.7)$ & $5(11.6)$ & $9(20.9)$ & \\
\hline $\mathrm{N} 3(>10)$ & $1(3.2)$ & $6(20.0)$ & $7(16.3)$ & $3(7.0)$ & \\
\hline Total & $31(100.0)$ & $30(100.0)$ & $43(100.0)$ & $43(100.0)$ & \\
\hline
\end{tabular}

*Fisher exact test; ER = estrogen; NOS = not otherwise specified

Table 3. Progesterone correlation with other parameters

\begin{tabular}{|c|c|c|c|c|c|c|}
\hline PR score & 0 & $2-5$ & 6 & 7 & 8 & $\mathrm{p}^{*}$ \\
\hline \multicolumn{7}{|l|}{ Histology } \\
\hline NOS & $7(77.8)$ & $33(78.6)$ & $16(69.6)$ & $24(66.7)$ & $22(59.5)$ & \multirow{3}{*}{0.593} \\
\hline lobular & $1(11.1)$ & $4(9.5)$ & $5(21.7)$ & $4(11.1)$ & $8(21.6)$ & \\
\hline others & $1(11.1)$ & $5(11.9)$ & $2(8.7)$ & $8(22.2)$ & $7(18.9)$ & \\
\hline \multicolumn{7}{|c|}{ Tumor size $(\mathrm{cm})$} \\
\hline$>0.5 \leq 1.0$ & $2(22.2)$ & $4(9.5)$ & $3(13.0)$ & $3(8.3)$ & $5(13.5)$ & \multirow{4}{*}{0.543} \\
\hline$>1 \leq 2$ & $3(33.3)$ & $17(40.5)$ & $6(26.1)$ & $10(27.8)$ & $14(37.8)$ & \\
\hline$>2 \leq 5$ & $2(22.2)$ & $20(47.6)$ & $12(52.2)$ & $20(55.6)$ & $14(37.8)$ & \\
\hline$>5$ & $2(22.2)$ & $1(2.4)$ & $2(8.7)$ & $3(8.3)$ & $4(10.8)$ & \\
\hline \multicolumn{7}{|l|}{ Grade } \\
\hline 1 & $3(33.3)$ & $16(38.1)$ & $13(56.5)$ & $11(30.6)$ & $21(56.8)$ & \multirow{3}{*}{0.008} \\
\hline 2 & $3(33.3)$ & $21(50.0)$ & $4(17.4)$ & $21(58.3)$ & $15(40.5)$ & \\
\hline 3 & $3(33.3)$ & $5(11.9)$ & $6(26.1)$ & $4(11.1)$ & $1(2.7)$ & \\
\hline \multicolumn{7}{|c|}{ Lymph node status } \\
\hline No & $4(44.4)$ & $17(40.5)$ & $8(34.8)$ & $15(41.7)$ & $22(59.5)$ & \multirow{4}{*}{0.832} \\
\hline N1 (1-3) & $1(11.1)$ & $10(23.8)$ & $7(30.4)$ & $9(25.0)$ & $7(18.9)$ & \\
\hline N2 (4-9) & $3(33.3)$ & $8(19.0)$ & $5(21.7)$ & $8(22.2)$ & $6(16.2)$ & \\
\hline N3 $(>10)$ & $1(11.1)$ & $7(16.7)$ & $3(13.0)$ & $4(11.1)$ & $2(5.4)$ & \\
\hline Total & $9(100.0)$ & $42(100.0)$ & $23(100.0)$ & $36(100.0)$ & $37(100.0)$ & \\
\hline
\end{tabular}

*Fisher exact test; $\mathrm{PR}$ = progesterone; NOS = not otherwise specified 
Table 4. Ki-67 correlation with other parameters

\begin{tabular}{|c|c|c|c|c|}
\hline $\begin{array}{l}\text { Ki-67 } \\
\text { index (\%) }\end{array}$ & $20-30$ & $31-40$ & $41-100$ & $\mathrm{p}^{*}$ \\
\hline \multicolumn{5}{|l|}{ Histology } \\
\hline NOS & $33(60.0)$ & $34(75.6)$ & $35(74.5)$ & \multirow{3}{*}{0.405} \\
\hline lobular & $10(18.2)$ & $5(11.1)$ & $7(14.9)$ & \\
\hline others & $12(21.8)$ & $6(13.3)$ & $5(10.6)$ & \\
\hline \multicolumn{5}{|c|}{ Tumor size $(\mathrm{cm})$} \\
\hline$>0.5 \leq 1.0$ & $10(18.2)$ & $4(8.9)$ & $3(6.4)$ & \multirow{4}{*}{0.421} \\
\hline$>1 \leq 2$ & $19(34.5)$ & $18(40.0)$ & $13(27.7)$ & \\
\hline$>2 \leq 5$ & $22(40.0)$ & $20(44.4)$ & $26(55.3)$ & \\
\hline$>5$ & $4(7.3)$ & $3(6.7)$ & $5(10.6)$ & \\
\hline \multicolumn{5}{|l|}{ Grade } \\
\hline 1 & $32(58.2)$ & $21(46.7)$ & $11(23.4)$ & \multirow{3}{*}{$<0.001$} \\
\hline 2 & $22(40.0)$ & $19(42.2)$ & $23(48.9)$ & \\
\hline 3 & $1(1.8)$ & $5(11.1)$ & $13(27.7)$ & \\
\hline \multicolumn{5}{|c|}{ Lymph node status } \\
\hline No & $31(56.4)$ & $19(42.2)$ & $16(34.0)$ & \multirow{4}{*}{0.413} \\
\hline N1 (1-3) & $9(16.4)$ & $12(26.7)$ & $13(27.7)$ & \\
\hline N2 (4-9) & $10(18.2)$ & $8(17.8)$ & $12(25.5)$ & \\
\hline $\mathrm{N} 3(>10)$ & $5(9.1)$ & $6(13.3)$ & $6(12.8)$ & \\
\hline Total & $55(100.0)$ & $45(100.0)$ & $47(100.0)$ & \\
\hline
\end{tabular}

*Fisher exact test; NOS = not otherwise specified ters such as lymph node metastasis, tumor size and histologic subtype (Tables 2-4).

On the Kaplan-Meier analysis, ER and PR scores were significantly associated with longer DFS (ER $\mathrm{p}=0.019$; and $\mathrm{PR} \mathrm{p}=0.038)$ and $\mathrm{OS}(\mathrm{ER} \mathrm{p}=0.020$; and $P R \mathrm{p}=0.026$ ); there was no statistically significant association of $\mathrm{Ki}-67$ with $\mathrm{OS}(\mathrm{p}=0.343)$ or DFS $(\mathrm{p}=0.322)$ (Fig. 1).

Univariate and multivariate Cox analysis was performed, including age, ER/PR score and Ki-67 proliferation index (Tables 5 and 6). For OS and DFS, PR was found to be a statistically significant independent prognostic parameter $(\mathrm{OS} \mathrm{p}=0.004$; and DFS $\mathrm{p}=0.029)$, while age was statistically correlated with OS $(\mathrm{p}<0.001)$. In this analysis, neither ER nor Ki-67 proliferation index seemed to have an independent role in OS and DFS.

\section{Discussion}

Luminal B (HER2 negative) subtype of breast cancer, as defined at the last 2015 St. Gallen Consensus in Vienna $2015^{5}$, is the most heterogeneous type of breast cancer compared to other subtypes determined by molecular gene profiling. As it is known, apart from previously listed histopathologic and molecular char-
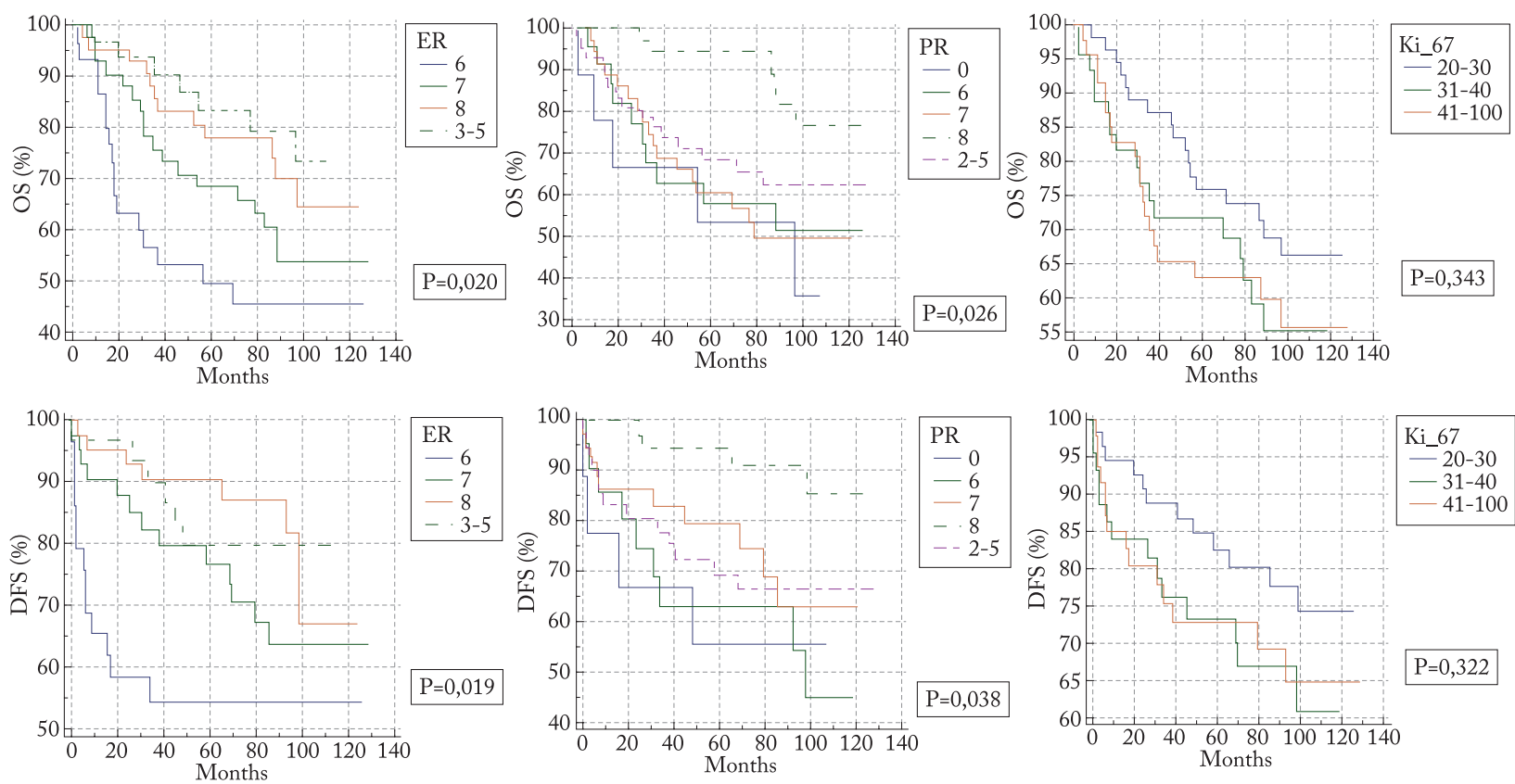

Fig. 1. Kaplan-Meier survival analysis of estrogen (ER), progesterone (PR) and Ki-67. 
Table 5. Univariate and multivariate prognostic analysis of 147 patients according to desease free survival

\begin{tabular}{|c|c|c|c|c|c|c|}
\hline \multirow{2}{*}{ Characteristic } & \multicolumn{3}{|c|}{ Univariate analysis } & \multicolumn{3}{|c|}{ Multivariate analysis } \\
\hline & HR & 95\% CI & $\mathrm{p}$ & HR & 95\% CI & $\mathrm{p}^{*}$ \\
\hline $\begin{array}{l}\text { Age (yrs) } \\
<66 \dagger\end{array}$ & 1.259 & $0.663-2.391$ & 0.482 & 1.448 & $0.748-2.801$ & 0.272 \\
\hline $\begin{array}{l}\mathrm{ER} \text { (score) } \\
\leq 7 \dagger\end{array}$ & 0.556 & $0.256-1.208$ & 0.138 & 0.594 & $0.270-1.306$ & 0.195 \\
\hline $\begin{array}{l}\text { PR (score) } \\
\leq 7 \dagger\end{array}$ & 0.257 & $0.091-0.723$ & 0.010 & 0.314 & $0.111-0.892$ & 0.029 \\
\hline $\begin{array}{l}\mathrm{Ki}-67(\%) \\
>26 \dagger\end{array}$ & 0.522 & $0.248-1.099$ & 0.087 & 0.539 & $0.253-1.150$ & 0.110 \\
\hline
\end{tabular}

*COX regression model; †cut off value determined by ROC analysis; $\mathrm{HR}=$ hazard ratio; $95 \% \mathrm{CI}=95 \%$ confidence interval; $\mathrm{ER}=$ estrogen; $\mathrm{PR}=$ progesterone

Table 6. Univariate and multivariate prognostic analysis of 147 patients according to overall survival

\begin{tabular}{|l|l|l|l|l|l|l|}
\hline \multirow{2}{*}{ Characteristic } & \multicolumn{4}{|l|}{ Univariate analysis } & Multivariate analysis & \\
\cline { 2 - 7 } & HR & $95 \%$ CI & $\mathrm{p}$ & HR & $95 \%$ CI & $\mathrm{p}^{*}$ \\
\hline $\begin{array}{l}\text { Age (yrs) } \\
<69 \dagger\end{array}$ & 3.246 & $1.887-5.584$ & $<0.001$ & 3.868 & $2.169-6.895$ & $<0.001$ \\
$\begin{array}{l}\text { ER (score) } \\
\leq 5 \dagger\end{array}$ & 0.485 & $0.219-1.075$ & 0.075 & 0.878 & $0.387-1.992$ & 0.755 \\
$\begin{array}{l}\text { PR (score) } \\
\leq 7 \dagger\end{array}$ & 0.299 & $0.128-0.700$ & 0.005 & 0.279 & $0.117-0.666$ & 0.004 \\
$\begin{array}{l}\text { Ki-67 (\%) } \\
>31 \dagger\end{array}$ & 0.604 & $0.339-1.076$ & 0.087 & 0.604 & $0.336-1.084$ & 0.091 \\
\hline
\end{tabular}

*COX regression model; †cut off value determined by ROC analysis; $\mathrm{HR}=$ hazard ratio; $95 \% \mathrm{CI}=95 \%$ confidence interval; $\mathrm{ER}=$ estrogen; $\mathrm{PR}$ = progesterone

acteristics, certain clinical characteristics are featured in this group, including worse relapse free survival, an increased risk of early relapse, predisposition to bone and pleural relapse, relative insensitivity to endocrine therapy (in comparison to luminal A subtype) and relative insensitivity to chemotherapy (in comparison to basal-like subtype $)^{8}$.

Sørlie et al. showed in their research that breast cancer could be divided into certain groups based on molecular profiling of genes, and they introduced a new concept of luminal $\mathrm{C}$ carcinoma as a distinct subtype that is linked with the worst outcome ${ }^{13}$. The expression of numerous genes, otherwise characteristic of basal-like and HER2 positive cancers, has been noticed in this subtype of cancer, in addition to ER and PR expression.

Recent researches of luminal B cancers, which show weaker intensity on hormone receptor staining or negative staining for one of the hormones, are also of great interest. Thus, Gloyeske et al. proved in their work that luminal B type with low ER intensity resembled the basal-like cancer morphologically, as well as by the degree of chemotherapy response ${ }^{14}$. Park et al. presented a group of cancers that were negative for one of the hormone receptors as a subgroup of luminal B (HER2 negative) cancers with worse prognosis ${ }^{15}$. It has also been demonstrated that luminal B subtype with low expression of ER has poorer complete pathologic response to neoadjuvant therapy, as compared with cancers with high expression. The response to neoadjuvant therapy is very much alike that of ER negative tumors, however, only in the group of luminal B HER2 negative subtype ${ }^{16}$.

Dvorkin-Gheva and Hassell found, by molecular profiling of genes in diverse breast cancers, that there were $35 \%$ of those that could not be placed in any of 
the five definitive subtypes of tumors, and argued that there was a specific category of luminal-like tumors characterized by high expression of ER and PR genes in $95 \%$ of cases $^{17}$. This subtype distinctly differs from the aforementioned luminal $\mathrm{C}$ subtype and, even though they have a low degree of HER2 amplification, the transcription profiles of genes similar to luminal A and $\mathrm{B}$ tumors were established in about $25 \%$ of cases. Clinical follow up established that this group of patients had better outcome than the basal-like subtype, although worse than the luminal A subtype. In daily routine, a large proportion of these tumors are certainly categorized using immunohistochemical methods as the luminal B (HER2 negative) subtype, and possibly these being the ones that show lower hormone expression rate along with poorer prognosis and disease outcome.

Through Kaplan-Meier curves, a statistically significant connection was found between lower ER and $\mathrm{PR}$ expression rate and worse disease outcome (OS and DFS), which is in accordance with recent researches and favors the distinct subtype of luminal B (HER2 negative) cancers that express lower hormone positivity and have a more aggressive course.

In their meta-analysis, the Early Breast Cancer Trialists' Collaborative Group (EBCTCG) proved that tamoxifen improved relapse free survival in ER positive tumors, independently of the PR status. On the other hand, Cancello et al. showed an interconnection of the negative $\mathrm{PR}$ receptors with a higher risk of disease relapse ${ }^{18}$. Furthermore, Zong et al. showed that the luminal B (HER2 negative) tumors had an increased risk of disease relapse when $\mathrm{PR}$ receptors were negative, even with well-conducted endocrine and adjuvant chemotherapies ${ }^{19}$. Using multivariate Cox regression analysis, in this study, a statistically significant impact of PR intensity on OS and DFS was established, implying the importance of negative or low positive $\mathrm{PR}$ expression as the isolated criterion in the assessment of disease outcome.

The American Society of Clinical Oncology and the College of American Pathologists (ASCO/CAP) have proposed that ER status should be considered positive if $1 \%$ or more tumor cells express nuclear positivity by immunohistochemical staining. Additionally, they suggest semiquantitative evaluation of immunohistochemical staining results (H-score or Allred method) ${ }^{20}$. It is well known that hormone therapy is applied in tumors with positive hormone receptors, however, only some $\mathrm{pa}^{-}$ tients with positive hormone receptors receive additional chemotherapy, mostly depending on the tumor biological characteristics ${ }^{21}$. Recent studies additionally demonstrate clinical importance of semiquantitative evaluation of hormone receptors, arguing that tumors with lower expression of hormone receptors can be, in addition to other parameters, a criterion for the introduction of chemotherapy ${ }^{22}$.

From this, it can be concluded that hormone receptor staining and percentage of positive staining cells is an important prognostic parameter in luminal B (HER2 negative) breast cancer. Furthermore, it can be concluded that the groups with lower intensity of positive hormone receptors, as well as those with one negative receptor can be placed into a unique group of luminal B (HER2 negative) breast cancer, based on the proven worse disease outcome and independently of most of the usual prognostic parameters.

The Ki-67 proliferation index is acknowledged as being important for distinction between luminal $\mathrm{A}$ and luminal B subtypes of cancer, in addition to estimation of a more aggressive disease course. In the given study group, all tumors had $\mathrm{Ki}-67$ value $>20 \%$. There were 17 tumors that had negative or low $(<20 \%)$ percentage of $\mathrm{PR}$ positive cells, yet all of these tumors had high Ki-67 proliferation index, and nevertheless had to be placed in the luminal B subtype. However, the Ki-67 proliferation index value had no impact on disease outcome in the presented group of patients and did not appear as a relevant factor regarding disease outcome.

The present study showed, by correlation analysis of ER and PR values and Ki-67 index with other clinical and pathologic parameters, a statistically significant correlation solely with tumor grade. Tumors with lower ER and PR intensity and higher Ki-67 proliferation activity were of a statistically significantly higher grade. Considering these results, it is concluded that in the group of tumors with weaker hormone positivity and those with higher $\mathrm{Ki}-67$ proliferation activity, the histologic grade of the tumor can be a significant parameter when more aggressive oncologic therapy is to be determined (in regard to other parameters including tumor size or axillary lymph node involvement).

Accordingly, besides molecular analyses and delicate gene profiling (which is unquestionably becoming 
necessary in the near future for malignant tumor diagnosis and analysis), the basic pathologic examination of tumor tissue remains a highly useful method, along with precise assessment of the parameters (percentage of tubule formation, degree of nuclear pleomorphism and accurate mitotic count) needed for tumor grading.

Finally, we conclude that the luminal B (HER2 negative) breast cancers with low hormone expression and independent of the Ki-67 proliferation index, might be a separate tumor group, and thus candidates for a more aggressive oncologic therapy. Independently of the new, modern methods of gene profiling, the old practice of histopathologic assessment of tumor grade and hormone receptor intensity, as well as the semiquantitative evaluation of $\mathrm{ER}$ and $\mathrm{PR}$ expression in tumor tissue are still essential in daily routine.

For better individual modification of oncologic therapy, the luminal B (HER2 negative) breast cancers should be additionally researched, and receptor intensity in this group of cancers could be an additional factor for adjuvant chemotherapy administration.

\section{References}

1. Baselga J, Norton L. Focus on breast cancer. Cancer Cell. 2002 May 1;1(4):319-22. doi: http:// dx. doi. org/ 10.1016/S15356108(02)00066-1

2. Žitnjak D, Soldić Z, Kust D, Bolanča A, Kusić Z. Demographic and clinicopathologic features of patients with primary breast cancer treated between 1997 and 2010: a single institution experience. Acta Clin Croat. 2015;54:295-302.

3. Kröger N, Milde-Langosch K, Riethdorf S, Schmoor C, Schumacher M, Zander AR, et al. Prognostic and predictive effects of immunohistochemical factors in high-risk primary breast cancer patients. Clin Cancer Res Off J Am Assoc Cancer Res. 2006 Jan 1;12(1):159-68. doi: 10. 1158/ 1078-0432.CCR-05-1340

4. Lesar M, Stanec M, Lesar N, Vrdoljak DV, Zore Z, Banović M, Brozović G. Immunohistochemical differentiation of triple negative breast cancer. Acta Clin Croat. 2016 Mar;55(1):3-8.

5. Coates AS, Winer EP, Goldhirsch A, Gelber RD, Gnant M, Piccart-Gebhart M, et al. Tailoring therapies - improving the management of early breast cancer: St Gallen International Expert Consensus on the Primary Therapy of Early Breast Cancer 2015. Ann Oncol Off J Eur Soc Med Oncol. 2015 Aug;26(8):1533-46. doi: 10.1093/annonc/mdv221. Epub 2015 May 4.

6. Ades F, Zardavas D, Bozovic-Spasojevic I, Pugliano L, Fumagalli D, de Azambuja E, et al. Luminal B breast cancer: molecular characterization, clinical management, and future perspectives. J Clin Oncol. 2014 Sep 1;32(25):2794-803.

doi: 10.1200/JCO.2013.54.1870
7. Colleoni M, Rotmensz N, Maisonneuve P, Mastropasqua MG, Luini A, Veronesi $\mathrm{P}$, et al. Outcome of special types of luminal breast cancer. Ann Oncol Off J Eur Soc Med Oncol. 2012 Jun;23(6):1428-36. doi: 10.1093/annonc/mdr461. Epub 2011 Oct 29.

8. Tran B, Bedard PL. Luminal-B breast cancer and novel therapeutic targets. Breast Cancer Res BCR. 2011;13(6):221. doi: 10.1186/bcr2904. Epub 2011 Nov 30.

9. Allred DC, Harvey JM, Berardo M, Clark GM. Prognostic and predictive factors in breast cancer by immunohistochemical analysis. Mod Pathol Off J U S Can Acad Pathol Inc. 1998 Feb;11(2):155-68

10. Dowsett M, Nielsen TO, A'Hern R, Bartlett J, Coombes RC, Cuzick J, et al. Assessment of Ki67 in breast cancer: recommendations from the International Ki67 in Breast Cancer working group. J Natl Cancer Inst. 2011 Nov 16;103(22): 1656-64. doi: 10.1093/jnci/djr393. Epub 2011 Sep 29.

11. Tavassoli FA, Devilee P: Pathology and Genetics: Tumours of the Breast and Female Genital Organs. WHO Classification of Tumours series, Volume IV. Lyon, France: IARC Press, 2003; p. 250.

12. Elston CW, Ellis IO. Pathological prognostic factors in breast cancer. I. The value of histological grade in breast cancer: experience from a large study with long-term follow-up. Histopathology. 1991;19(5):403-10.

13. Sørlie T, Perou CM, Tibshirani R, Aas T, Geisler S, Johnsen H, et al. Gene expression patterns of breast carcinomas distinguish tumor subclasses with clinical implications. Proc Natl Acad Sci. 2001 Sep 11;98(19):10869-74. doi: 10.1073/pnas.191367098

14. Gloyeske NC, Dabbs DJ, Bhargava R. Low ER+ breast cancer: is this a distinct group? Am J Clin Pathol. 2014 May;141(5): 697-701. doi: 10.1309/AJCP34CYSATWFDPQ

15. Park C, Park K, Kim J, Sin Y, Park I, Cho H, et al. Prognostic values of negative estrogen or progesterone receptor expression in patients with luminal B HER2-negative breast cancer. World J Surg Oncol. 2016;14:244. doi: 10.1186/s12957-0160999-x

16. Landmann A, Farrugia DJ, Diego E, Soran A, Johnson R, Bonaventura $\mathrm{M}$, et al. Low estrogen receptor (ER) positive breast cancer and neoadjuvant systemic therapy (NAT): is response similar to ER+ or to ER- disease? J Clin Oncol. 2016;34 Suppl 15:S580. doi: 10.1200/JCO.2016.34.15_suppl.580

17. Dvorkin-Gheva A, Hassell JA. Identification of a novel luminal molecular subtype of breast cancer. PloS One. 2014;9(7): e103514. https://doi.org/10.1371/journal.pone.0103514

18. Cancello G, Maisonneuve P, Rotmensz N, Viale G, Mastropasqua MG, Pruneri G, et al. Progesterone receptor loss identifies luminal B breast cancer subgroups at higher risk of relapse. Ann Oncol Off J Eur Soc Med Oncol. 2013 Mar;24(3):661-8. doi: 10.1093/annonc/mds 430. Epub 2012 Sep 28

19. Zong Y, Zhu L, Wu J, Chen X, Huang O, Fei X, et al. Progesterone receptor status and ki-67 index may predict early relapse 
in luminal B/HER2 negative breast cancer patients: a retrospective study. PLOS One. 2014 Aug 29;9(8):e95629. https:// doi.org/10.1371/journal.pone.0095629

20. Hammond ME, Hayes DF, Dowsett M, Allred DC, Hagerty KL, Badve S, et al. American Society of Clinical Oncology/ College of American Pathologists guideline recommendations for immunohistochemical testing of estrogen and progesterone receptors in breast cancer (unabridged version). Arch Pathol Lab Med. 2010 Jul;134(7):e48-72. doi: 10.1043/1543-2165134.7.e48
21. Gnant M, Thomssen C, Harbeck N. St. Gallen/Vienna 2015: A Brief Summary of the Consensus Discussion. Breast Care Basel Switz. 2015 Apr;10(2):124-30. doi: 10.1159/000430488

22. Cuzick J, Dowsett M, Pineda S, Wale C, Salter J, Quinn E, et al. Prognostic value of a combined estrogen receptor, progesterone receptor, $\mathrm{Ki}-67$, and human epidermal growth factor receptor 2 immunohistochemical score and comparison with the Genomic Health recurrence score in early breast cancer. J Clin Oncol Off J Am Soc Clin Oncol. 2011 Nov 10;29(32):4273-8. doi: 10.1200/JCO.2010.31.2835. Epub 2011 Oct 11

Sažetak

\section{PROGNOSTIČKI UTJECAJ NISKOG POZITIVITETA ESTROGENIH I PROGESTERONSKIH RECEPTORA U LUMINALNIM B (HER2 NEGATIVNIM) KARCINOMIMA DOJKE}

\section{J. Rajc, I. Fröblich, M. Mrčela, I. Tomaš i J. Flam}

Luminalni B (HER 2 negativni) karcinomi dojke najheterogenija su podskupina s velikim rasponom proliferacijskog indeksa Ki-67 kao i intenziteta te raspodjele hormonskih receptora unuatar tumorskih stanica. Također je zamjetna različitost u kliničkom ishodu bolesti, zbog čega se ukazuje potreba za detaljnijom subtipizacijom ove skupine tumora. Izdvojeno je 147 luminalnih B HER2 negativih karcinoma, a ispitani su kliničko-patološki parametri u korelaciji s intenzitetom hormonskih receptora (estrogen (ER) i progesteron (PR)) kao i Ki-67 u odnosu na sveukupno preživljenje te preživljenje bez povrata bolesti. Unutar ispitivanih kliničko patoloških parametara slabiji intenzitet hormonskih receptora kao i viši Ki-67 bili su statistički značajno povezani samo s gradusom tumora. Kaplan-Meierovom analizom ustanovljena je statistički značajna povezanost slabog intenziteta ER i PR s preživljenjem (sveukupno preživljenje (ER), $\mathrm{p}=0,020$; preživljenje bez povrata bolesti (ER), $p=0,019$; sveukupno preživljenje (PR), $\mathrm{p}=0,026$; preživljenje bez povrata bolesti (PR), $\mathrm{p}=0,038)$ ), za razliku od Ki-67 vrijednosti kojega nisu bile statistički značajno povezane s preživljenjem (sveukupno preživljenje, $\mathrm{p}=0,343$; preživljenje bez povrata bolesti, $\mathrm{p}=0,322$ ). Coxovom regresijskom analizom $\mathrm{PR}$ se pokazao kao statistički značajan neovisni parametar povezan sa sveukupnim preživljenjem $(\mathrm{p}=0,004)$ i preživljenjem bez povrata bolesti $(\mathrm{p}=0,029)$. Ovi rezultati pokazuju da bi podskupina luminalnih B HER2 negativnih karcinoma dojke s niskim intenzitetom hormonskih receptora, neovisno o proliferacijskom indeksu Ki-67, a u korelaciji s histološkim gradusom tumora mogla biti zaseban podtip karcinoma dojke.

Ključne riječi: Dojka, tumori; Receptori, estrogen; Receptori, progesteron; Preživljavanje bez bolesti; Hrvatska 